Журнал «Герспективитаінноваціїнауки»

(Серія «Педагогіка», Серія «Гиихологія», Серія«Медицина»

№5(5) 2021

УДК 373.3/.5.016:5]:004

https://doi.org/10.52058/2786-4952-2021-5(5)-364-374

Качмар Олександра Василівна доктор філософських наук, професор, кандидат педагогічних наук, викладач мистецьких дисциплін, доцент кафедри фахових методик і технологій початкової освіти педагогічного факультету, Прикарпатський національний університет імені Василя Стефаника, вул. Бандери, 1, м. Івано-Франківськ, 76000, тел. (0342) 57-00-10, e-mail: kfmtpo@pnu.edu.ua, https://orcid.org/0000-0002-2002-4603

Барило Світлана Богданівна доцент, кандидат педагогічних наук, кафедра фахових методик i технологій початкової освіти педагогічного факультету, Прикарпатський національний університет імені Василя Стефаника, вул. Бандери,1, м. Івано-Франківськ, 76000, тел.: (0342) 57-00-10, e-mail:kfmtpo@pnu.edu.ua, https://orcid.org/0000-0001-7052-9442

Добровольська Руфіна Олегівна асистент кафедри мистецьких дисциплін дошкільної та початкової освіти факультету дошкільної та початкової освіти імені Валентини Волошиної, Вінницький державний педагогічний університет імені Михайла Коцюбинського, вул. Острозького, 32, Вінниця, 21001, e-mail: Rufina.dobrovolska@ vspu.edu.ua, https://orcid.org/0000-0002-1414-8861

\title{
СУТНІСТЬ ТА ІННОВАЦІЙНИЙ ПОТЕНЦАЛ ВИКОРИСТАННЯ ДОПОВНЕНОЇ РЕАЛЬНОСТІ В ПОЧАТКОВІЙ ШКОЛІ
}

Анотація. Навколишній світ змінюється навіть не щороку і не щомісяця. Він щодня стає іншим, розвивається, йде вперед. Слідом за ним розвиваються усі галузі, і в тому числі освітня. Вона найперша реагує на будь-які зміни, адже саме від неї залежить якість розвитку суспільства. Освіта має враховувати усі вимоги суспільства, аби забезпечити його стабільне функціонування та розвиток. За останні кілька десятиліть суттєво змінилися стандарти освіти. Якщо раніше вони були орієнтовані на отримання та засвоєння знань, то тепер здобувачів освіти вчать навчатися протягом усього життя, уміти змінювати вектори розвитку та інтегрувати будь-які знання у практичну діяльність. Саме тому широкої популярності набули інтерактивні технології та технології доповненої реальності. Зі стрімкими змінами в науці та техніці змінюється й людство. Останнє покоління, яке вчені називають поколінням Z, не просто живе у світі інформації, воно в ньому народилося. Таким дітям часом складно розмежувати реальний світ та віртуальний. А відтак, і сприймання інформації у них відрізняється від традиційного засвоєння. Дослідження психологів, соціологів та педагогів показали, що найкраще покоління «зетів» сприймає інформацію блоками. Крім того, вона має бути візуалізована, систематизована 
та упорядкована. Тоді їм легше побудувати логічні зв'язки між різними навчальними дисциплінами та предметами. Технології доповненої реальності цілком відповідають вимогам нових стандартів освіти, оскільки вони дозволяють розвивати дослідницькі уміння, зорову, образну та логічну пам'ять, уяву, фантазію, формують навички дистанційного навчання, роботи в парах та групах тощо. Технології доповненої реальності охоплюють чи не усі сфери суспільства. I це дає змогу таким чином формувати навчальний матеріал, щоб він створював цілісну картину уявлень дитини про оточуючий світ. До таких технологій відносяться інтерактивні підручники та посібники, додатки 3 технологіями доповненої реальності, освітні платформи та ресурси, що також використовують доповнену реальність.

Отже, широкі можливості застосування технологій доповненої реальності дають підстави стверджувати, що їх використання в початковій школі $\epsilon$ ефективним та необхідним.

Ключові слова: доповнена реальність, інтеграція, візуалізація, інноваційні технології

Kachmar Oleksandra Vasylivna Doctor of philosophical sciences, professor, candidate of pedagogical sciences, teacher of art disciplines, associate professor Department of Professional Methods and Techniques of Primary Education Faculty of Pedagogy Vasyl Stefanyk Precarpathian National University, St. Bandery St.,1, Ivano-Frankivsk, 76000, tel.: (0342) 57-00-10, e-mail: kfmtpo@ pnu.edu.ua, https//orcid.org/0000-0002-2002-4603

Barylo Svitlana Bohdanivna Associate Professor, Candidate of Pedagogical Sciences, Department of Professional Methods and Techniques of Primary Education Faculty of Pedagogy Vasyl Stefanyk Precarpathian National University, St. Bandery St., 1, Ivano-Frankivsk, 76000, tel.:(0342) 57-00-10, e-mail: kfmtpo@pnu.edu.ua, https//orcid.org/0000-0001-7052-9442

Dobrovolska Rufina Olehivna Assistant of the Department of Art Disciplines of Preschool and Primary Education, PhD, Department of Art Disciplines of Preschool and Primary Education Faculty of Preschool and Primary Education named after V. Voloshyna, Vinnytsia Mykhailo Kotsyubynsky State Pedagogical University, Ostroh St., 32, Vinnytsia, 21001, tel.: (093) 891-65-17, e-mail: Rufina.dobrovolska@vspu.edu.ua,https://orcid.org/0000-0002-1414-8861

\section{ESSENCE AND INNOVATIVE POTENTIAL OF THE USE OF ENGAGED REALITY IN PRIMARY SCHOOL}

Abstract. The world around us does not change every year or every month. He becomes different every day, develops, moves forward. It is followed by all industries, including education. It is the first to react to any changes, because it 
depends on the quality of society. Education must take into account all the requirements of society to ensure its stable functioning and development. Education standards have changed significantly over the last few decades. If before they were focused on acquiring and mastering knowledge, now students are taught to learn throughout life, be able to change the vectors of development and integrate any knowledge into practice. That is why interactive technologies and augmented reality technologies have become widely popular. With the rapid changes in science and technology, humanity is changing. The last generation, which scientists call Generation Z, does not just live in the world of information, it was born in it. It is sometimes difficult for such children to distinguish between the real world and the virtual world. Consequently, their perception of information differs from traditional assimilation. Research by psychologists, sociologists and educators has shown that the best generation of "zets" perceive information in blocks. In addition, it must be visualized, systematized and organized. Then it is easier for them to build logical connections between different disciplines and subjects. Augmented reality technologies fully meet the requirements of new educational standards, as they allow to develop research skills, visual, figurative and logical memory, imagination, fantasy, form distance learning skills, work in pairs and groups and more. Augmented reality technologies cover almost all spheres of society. And this makes it possible to form educational material in such a way that it creates a holistic picture of the child's ideas about the world around him. Such technologies include interactive textbooks and manuals, applications with augmented reality technologies, educational platforms and resources that also use augmented reality. Thus, the wide range of possibilities for the application of augmented reality technologies gives grounds to assert that their use in primary school is effective and necessary.

Keywords: augmented reality, integration, visualization, innovative technologies

Постановка проблеми. Сучасний світ надміру цифровізований та диджиталізований. Проте це не його недолік, а вимога часу та результат технічного прогресу. Величезна кількість гаджетів суттєво полегшує життя не лише домогосподарок чи тих, хто працює дистанційно, а й тих, хто навчається.

Перелік послуг, які можна отримати чи виконати дистанційно, за допомогою мережі Інтернет та гаджетів, чималий: від сплати за товар до замовлення квитків та віртуальних подорожей. I щороку цей перелік збільшується. Технології стрімко розвиваються і поширюються світом, охоплюючи щоразу більшу кількість галузей. Освітня галузь входить у першу десятку, оскільки саме від неї залежить не тільки подальший розвиток, а й ефективне функціонування суспільства з урахуванням усіх вимог часу.

Зокрема, Нова українська школа працює за новими стандартами, які передбачають широке застосування різноманітних гаджетів, у тому числі й смартфонів, та використання освітніх платформ та систем. Проте варто зазначити, що звичайний інтерактив, яким послуговувалися вчителі ще 
буквально кілька років тому, уже не «спрацьовує» або принаймні не має того ефекту, який потрібен. Скажімо, сервіс Learning Apps пропонує широкий спектр різноманітних вправ. Однак вчителі-практики помітили цікаву тенденцію: чим молодші учні, яким пропонується використання цього сервісу, тим менше їх цікавить виконання завдань такого роду.

Відтак, перед освітою нині постає ряд завдань: створити комфортні умови для здобувачів освіти, аби вони мали можливість не просто отримувати знання, a й інтегрувати їх у практичну діяльність та застосовувати на практиці. Традиційні методи та прийоми не спрацьовують. Отже, вкрай необхідно подавати інформацію поколінню «Зет» (або як їх ще називають digitalnative) так, щоб отримати якнайсильніший ефект.

Відомо, що найбільшу частку інформації людина сприймає зором (навіть попри поділ на різні типи сприймання: кінестетики, візуали, аудіали, дискрети). Тому саме візуалізація (разом 3 інтерактивом) здатна не просто зацікавити учнів, а й утримати їхню увагу, захопити процесом, сприяти кращому розумінню та запам'ятовуванню. Проблема доповненої реальності, іiі використання у початковій школі, $\epsilon$ актуальною та важливою сьогодні, оскільки саме початкова школа дає підгрунтя для подальшої освіти (базової, профільної, професійної).

Аналіз останніх досліджень і публікацій. Наукові дослідження останніх років засвідчують, що технології візуалізації та доповненої реальності відвойовують все більше місця у галузі освіти. Проте, попри широкий інтерес теоретиків та практиків до цієї теми, вона є малодослідженою, зокрема, що стосується початкової школи. В умовах пандемії COVID-19 та зважаючи на карантинні обмеження, викликані цим, освітяни (і не тільки вони) змушені використовувати дистанційні форми роботи.

Відтак, навчальний матеріал повинен бути доступним, зрозумілим, наочним. Серед вітчизняних дослідників цієї теми досліджують можливості доповненої реальності, їх впровадження у освітні тренди Мельник I. [1], Житеньова Н. [2], Гончарова Н. [3], Корнієнко I. [4], Сороко Н. [5] та інші.

Питання впровадження технології доповненої реальності досліджували також зарубіжні науковці: Ю. Счкало [6], Д. Мізелл, Т. Кауделл, В. Ткачук [7] тощо. Ця технологія застосовується майже в усіх сферах діяльності суспільства (інженерія, архітектура, бізнес-проєкти, IT тощо), а тому цікавить і педагогів, оскільки дає широкі можливості для використання i як дидактичного матеріалу, і як цілком самодостатньої системи знань.

Мета статті. Основною метою статті $є$ аналіз сутності та інноваційності технології доповненої реальності, іiі впровадження в навчальний процес початкової школи, а також визначення можливості та особливості іiі застосування в освітньому процесі.

Виклад основного матеріалу. Сучасне покоління визначається вченими як покоління Z (або «цифрові діти»). Вони народилися в епоху глобальної мережі та панування гаджетів, без яких вони не уявляють свого існування. 
Якщо попередні покоління (навіть і те, що передує «зетам») розділяли й розділяють навколишній світ на матеріальний та цифровий, то для «зетів» такого поділу не існує. Їх світ всуціль віртуальний, невіддільний від оточуючого. Ці діти не просто легко орієнтуються у цифровому світі, вони в ньому існують. Це відповідно спричинює особливості сприймання ними інформації. Аби розуміння й відтворення такими дітьми інформації було успішним, вона має подаватися блоками, причому бажано інтерактивними. Інакше її просто обійдуть увагою.

Саме тому базовим принципом Нової української школи $є$ інтеграція, що передбачає поєднання знань 3 різних наук 3 метою глибокого розуміння картини світу. Ключові компетентності НУШ (Нова українська школа) враховують і те, що здобувачі освіти вмітимуть не тільки отримувати знання, а й впроваджувати їх у своїй діяльності протягом життя, вмітимуть навчатися та адаптуватися в соціумі.

Разом зі змінами в стандартах освіти для початкової школи змінилися й підручники, посібники, робочі зошити та інші дидактичні матеріали. Переважна більшість із них містить інтерактивний компонент. Зокрема, підручник для 2 класу «Я досліджую світ» (Волощенко О., Козак О., Остапенко Г.) містить в своїй структурі QR-коди, за якими можна переглянути відео до певної теми, відвідати віртуальну екскурсію, переглянути відеорозповідь або дізнатися додаткову інформацію. Підручник 3 української мови (Большакова I., Пристінська М.) містить посилання на електронну платформу (http://interactive.ranok.com.ua), де розміщені онлайн уроки та курси 3 усіх тем предмету. Підручник з англійської мови (Карпюк О.) також містить посилання на ресурс, де можна використовувати аудіосупровід для цього підручника (https://lib.imzo.gov.ua). Підручник 3 мистецтва (Масол Л., Гайдамака О., Колотило О.) пропонує за посиланнями прослухати музичні твори або руханки.

Таким чином, підручники початкової школи суттєво відрізняються від тих, якими користується старша школа, адже книги для молодших школярів орієнтовані на комплексне сприймання інформації.

Технологія доповненої реальності $\epsilon$ складником галузі штучного інтелекту. Префікс smart(англ. - розумний) уже давно увійшов у щоденний побут і молодшого, і старшого покоління. Смартфони, смарт-дошки, смартгодинники і навіть смарт-будинки ще років сто-двісті існували лише на сторінках фантастичних романів, а сьогодні стали повсякденною реальністю. Згадаймо хоча 6 Р. Бредбері та його «451 за Фаренгейтом», у якому він детально описав технології плазмових телевізорів (відео-стіни в будинку головного героя), бездротових навушників та електронних пристроїв (типу сучасних айпадів).

Доповнена реальність швидко набирає обертів у освітній галузі. I це не лише «оживлення» літературних творів, а й віртуальні лабораторії, STEMпроєкти й дослідження, подорожі тощо. 
Звернімо увагу на STEM-освіту, якій зараз приділяють не менше уваги, ніж доповненій реальності. Поєднання базових понять і принципів науки, техніки, інженерії та математики дає можливість учням не лише якісно сприймати інформацію, а й формує науковий світогляд. STEM-проєкти наразі впроваджують і в дошкільній освіті, хоча й у спрощеній формі (створення лепбуків, інтерактивних плакатів, карт тощо).

Завдання учителя початкової школи - дати базові знання, навички, без яких неможлива подальша освіта. Та часом це важко зробити, адже утримати увагу дітей на уроці складно. Тоді на допомогу й приходить візуалізація та доповнена реальність. Якщо згрупувати технології доповненої реальності, то можна визначити такі основні напрями:

- підручники або книги з доповненою реальністю (QR-коди, активні посилання тощо);

- кубики 3 доповненою реальністю (з їх допомогою можна вивчати звуки та слова - для дітей 3 особливими потребами або першокласників);

- навчальні посібники 3 доповненою реальністю (аудіосупровід, відеоуроки тощо);

- 3D розмальовки;

- додатки з доповненою реальністю.

У багатьох школах України використовують смарт-дошки. Проте вони розраховані на учнів середньої та старшої школи, оскільки працювати з ними складнувато для молодших школярів. Саме тому доволі зручними та ефективними $є$ технології доповненої реальності. У поєднанні зі STEMтехнологіями вони допомагають дітям поступово перейти від ігрової діяльності до безпосередньо процесу навчання.

Розглянемо детально можливості використання технологій доповненої реальності на конкретних прикладах. При вивченні теми «Тварини» (природнича галузь) запропоновано створити STEM-проєкт «Динозаври». Проєкт розрахований на декілька місяців, охоплює діяльність кількох класів та всіх навчальних дисциплін.

На уроках української мови учні мали складати розповіді (казки, віршики тощо) про динозаврів з використанням інтерактивних презентацій, складених учителем. Практична мета цього завдання - збагачення словникового запасу учнів, розвиток комунікативних та читацьких умінь (адже для створення розповіді вони були змушені шукати додаткову інформацію), розвиток творчих здібностей (не лише складання творів, а й акторське подання - виразне читання, театралізація). Як результат такої роботи - створення мультимедійного збірника учнівської творчості (з можливістю подальшого використання для інших класів).

На уроках математики учні повинні обчислити приблизний розмір динозаврів, а також - вирахувати дату їх існування. Це дає можливість усвідомити наскільки відрізнялися тварини сьогодення та давнини. 
Результатом цієї роботи можуть бути узагальнювальні порівняльні таблиці, створені самими учнями.

На уроках ЯДС (Я досліджую світ) діти можуть створити паперові (пластилінові, глиняні, 3 тіста або лего-фігурки) динозаврів, спочатку переглянувши візуалізовані образи 3 книг. Зокрема, книги видавництва «Talantbooks» (серія IExplore) пропонують дітям «запросити» у реальний світ доісторичних тварин, динозаврів, комах та морських істот. Візуалізовані образи не тільки постають перед учнями в 3D-моделях, які можна покрутити, рухати ними, а й видають звуки, створюючи ефект повної присутності. Тварин можна збільшувати, зробити з ними фото або відео з подальшим збереженням.

На уроках англійської мови учням пропонують створити й записати відео англійською мовою (про динозаврів). Крім того, вони добирають слова (тематичну лексику), які могли б стосуватися динозаврів (колір, розмір, дії тощо). Завдання спрямовані на вивчення лексики, засвоєння граматичних норм, умінь формулювати думки англійською. Як результат цієї діяльності створення мультимедійного диску з роботами учнів.

На уроках інформатики діти створюють малюнки динозаврів, анімують їх, розвиваючи вміння програмування та роботи з цифровими додатками.

Отже, бачимо, що можливості використання технологій доповненої реальності необмежені.

У сучасній освіті $€$ достатньо програм та додатків 3 доповненою реальністю, проте розраховані вони переважно на учнів старших класів (навчальний матеріал з фізики, хімії, географії). Відтак, для учнів початкової школи використовуються лише деякі технології. Тому цей напрям потребує не тільки всебічного аналізу, а й подальшого розвитку.

Враховуючи те, що вищезазначені додатки розраховані на дітей старшого віку, їх необхідно адаптувати для молодших школярів. При цьому обов'язково звертаючи увагу на те, що й самі додатки стрімко розвиваються. I те, що ще вчора зацікавлювало дітей, завтра цілком можливо буде їм абсолютно байдужим. Психологи вважають, що дітям нових поколінь властиве «кліпове мислення», тобто, вони сприймають інформацію невеликими блоками. Проте такі блоки $є$ дуже насиченими, бо апелюють одночасно до різних органів сприйняття. Скажімо, при вивченні теми «Територія» проста розповідь або звичайна мапа навряд чи зацікавить дітей, навіть якщо вона буде деталізована й матиме якісь вже відомі дітям об'єкти. А от якщо їм показати додаток GoogleEarth, яке дає можливість побачити будь-яку точку земної кулі настільки детально, наскільки на даний момент це можливо, то це захопить їх. Робота $з$ цим додатком розвиває не тільки увагу дітей, а й уявлення про розміри, географічне положення (міста, селища, річки тощо), відстань, координати та інше. Додаток може показувати об'єкти у форматі 2D або 3D. Знайти на мапі можна не тільки визначні місця, пам'ятники, храми та інше, а й знайомі вулиці, майданчики, будь-які місця, що вже відомі дитині.

Приблизно такі ж функції має інтерактивний глобус (наприклад, Intboard 
Globus Orboot). За допомогою програмового забезпечення встановленого на девайсі (телефон, планшет) можна розглядати різні куточки світу, дізнатися цікаві факти про місцевість, ландшафт, природу або тваринний чи рослинний світ певного регіону. Додаток до глобусу містить доповнену реальність, яка в інтерактивному форматі дає дитині знання, задіюючи при цьому іiі слух, зір, увагу, активну пам'ять, уяву та логічне й образне мислення.

Дуже цікавим є також додаток StarWalk 2 Ads від Google, який демонструє мапу зоряного неба, подає відомості про астрономічні тіла, сузір'я, планети, супутники, галактики. Він не адаптований для використання в школі, проте має великий потенціал. Адже 3 його допомогою можна дізнатися інформацію про будь-яке небесне тіло, його розташування в режимі реального часу. Крім того, можна відслідковувати об'єкти не лише в просторі, а й у часі. Атлас зоряного неба містить окрім планет ще й туманності, скупчення, метеорні потоки та інші не менш цікаві об’єкти у форматі 3D моделей.

Уже кілька років поспіль в Україні проводиться так званий «Інженерний тиждень» для здобувачів освіти будь-якого віку. Це заходи проєкту, розраховані на формування технічної, інженерної освіти. Протягом тижня (хоча він триває більше за часовим проміжком) учні поглиблюють знання 3 різних галузей науки та техніки, дізнаються про великих винахідників та їх винаходи, а головне - самостійно вирішують інженерно-технічні завдання, створюючи певні об'єкти, моделі, пристрої чи іграшки.

На жаль, більша частина віртуальних лабораторій (з фізики, хімії, географії, математики, історії, біології тощо) створені для старшої школи (https://www.golabz.eu ). Відтак, молодшим школярам ця інформація буде занадто складною для опанування та розуміння. Проте частина завдань Інженерного тижня передбачає й участь найменших здобувачів освіти. Зокрема, у попередні роки учні 1-4 класів створювали вежі з паличок та досліджували їх витривалість, вивчали властивості снігу та льоду (їх вигляд, вплив на них інших речовин), створювали ланцюжок 3 паперу, вимірювали його довжину тощо.

Робота учнів початкових класів 3 такими завданнями готує їх до більш глибокого вивчення природничих та математичних дисциплін, оскільки у спрощеному, доступному вигляді дає початкові уявлення про фізичні та хімічні процеси, роботу пристроїв та механізмів.

Дослідження якості освіти PISA показало, що українські підлітки мають проблеми й труднощі із застосуванням отриманих знань на практиці. Дослідники вважають, що причина такого явища у тому, що після закінчення початкової школи учні стрімко втрачають інтерес до науки, адже не бачать можливостей застосування знань та навичок у повсякденному житті.

Тому робота вчителів початкової школи має бути спрямована на те, аби виховати стійкий інтерес до процесу навчання, якомога ширше охопити різні галузі науки, техніки, мистецтва за допомогою інтеграції та постійного застосування візуалізації та інтерактивних технологій. 
Використовувати доповнену реальність можна не тільки при вивченні природничих чи математичних наук, а й гуманітарних. Проте знову ж таки, найбільш широкі можливості доступні для старшої школи. А початкова школа обмежується тим, що пропонують підручники та дидактичні посібники.

С. Паламар зазначає: «Розвиваючи в учнів початкової школи навички навчання протягом життя, важливо сформувати інтерес до книжок, навчити відчувати пре-красне, що закладено в художньому слові. Глибина сприйняття твору залежить не тільки від розвитку критичного мислення та естетичного чуття, пов'язаного з відчуттям краси, розумінням цінностей, що акумулюються в художньому образі, а й від емоційного інтелекту. Тому розвиткові діалогової взаємодії з творами мистецтва значною мірою сприятиме застосування технології доповненої реальності, що викликає своєю візуалізацією передовсім емоційний резонанс і сприяє активізації творчої уяви» [8].

Вивчення англійської мови за допомогою доповненої реальності сприяє кращому засвоєнню матеріалу, допомагає відпрацювати мовні та мовленнєві навички. Зокрема, посібники 3 доповненою реальністю подають до кожної теми відео (це може бути навчальне відео або просто мультфільм, де персонажі розмовляють англійською). Це сприяє збагаченню лексичного запасу дитини. Персонажі промовляють (або співають) слова, формуючи при цьому фонетичні та орфоепічні навички учнів. Ігрова форма здатна тримати увагу дітей довше, аніж звичайний урок (у вигляді пояснень чи лекцій). На етапі закріплення матеріалу дитина повторює слова, фрази, речення, виконує прості завдання чи сама створює такі. Тим самим візуалізований навчальний матеріал засвоюється на достатньому та високому рівнях.

Інформатична освітня галузь знайомить учнів початкової школи 3 графічними редакторами, комп'ютерними пристроями, учить створювати малюнки та виконувати нескладні дії з ними. Як додаткові теми пропонується використання графічних редакторів онлайн, а також за допомогою смартфонів. Отже, інформатика як навчальний предмет має найширші можливості для використання технологій доповненої реальності, оскільки будь-який гаджет тим чи іншим чином пов'язаний з пристроями (гаджетами, девайсами) та роботою з ними.

Скажімо, цікавим є проєкт з програмування «Нова школа від Minecraft», де діти створювали власну школу на базі однойменної гри. Тривимірна модель школи $з$ відповідною анімацією - це також різновид технологій доповненої реальності. Розрахований проєкт був на учнів 6-8 класів, проте як один варіантів може бути корисний та цікавий також і учням молодшої школи.

Оскільки Нова українська школа передбачає інтеграцію навчальних предметів та дисциплін, то технології доповненої реальності якнайкраще сприяють реалізації цього принципу.

Підручники або книги 3 технологією доповненої реальності містять посилання на відео (що відтворюється або на певній платформі, або на ресурсі 
YouTube), інтерактивні ілюстрації, аудіозаписи, анімацію чи навіть гру (за певним тематичним сюжетом). Цей контент розроблений відповідно до стандартів початкової освіти, він враховує вікові та психофізіологічні особливості дітей молодшого віку, спрямований не лише на розвиток логіки, конкретного та абстрактного мислення, а й уяви, фантазії та творчих здібностей.

Таким чином, технології доповненої реальності дозволяють вивчати навколишній світ у тісному взаємозв'язку між його частинами (різні галузі). Розвиток мультимедійного контенту для підручників молодшої школи йде у напрямку 4D моделювання (тобто об'ємні моделі з анімацією).

Висновки. Отже, підсумовуючи вищезазначене, можна зробити висновок, що технології доповненої реальності мають потужний освітній та виховний потенціал. Ïї використання в навчально-виховному процесі сприятиме кращому розумінню, засвоєнню, а в подальшому - i застосуванню отриманих знань. Сучасний світ $\epsilon$ таким, що вимагає від людини вміння постійно навчатися, бути гнучким до змін у технічному прогресі. За прогнозами соціологів, у найближчі десятиліття велика кількість традиційних професій зникне. Натомість з'явиться перелік інших, які вимагатимуть кардинально нових знань і навичок, адже вони поєднуватимуть інформацію та знання з різних, часом протилежних чи несумісних дисциплін.

Відтак, основною задачею освітян $є$ підготувати дитину до життя в такому суспільстві, допомогти їй адаптуватися та скоординувати вектор іiі особистого розвитку.

Візуалізація начального матеріалу та освітнього процесу в цілому суттєво підвищує не лише рівень знань, а й мотивацію до навчання, привчатиме учнів працювати самостійно, в команді, дистанційно. Звісно, це вимагатиме переорієнтації вчителів на трохи інший спосіб подання інформації, а також потребуватиме достатньо глибокої та грунтовної підготовки до уроків.

Таким чином, можна спрогнозувати вектори розвитку технологій доповненої реальності для наступних досліджень:

- вивчення та застосування зарубіжного досвіду використання технології доповненої реальності;

- інтеграція традиційних методів навчання 3 інтерактивними технологіями;

- STEM-освіта в контексті технологій доповненої реальності.

\section{Лimepamypa:}

1. Мельник І. Доповнена та віртуальна реальність як ресурс навчальної діяльності студентів. Інформащійні технології та комп'ютерне моделювання: матеріали статей Міжнародної науково-практичної конференції, (м. Івано-Франківськ, 14-19 травня 2018 року). Івано-Франківськ: п. Голіней О.М., 2018. С. 61-64.

2. Житеньова Н. Технології візуалізації в сучасних освітніх трендах. Відкрите освітне е-середовище сучасного університету. 2016. № 2. С. 170-178.

3. Гончарова Н. Технологія доповненої реальності в підручниках нового покоління. Проблеми сучасного підручника. 2019. № 22. С. 46-56. 
4. Korniienko I. O. Augmented reality tools in education. Visnyk National Defence Unuversity of Ukraine.2020. Vol.57.4. P. 52-58.

5. Soroko N. The augmented reality functions to support the STEAM education at general education institutions. Physical and Mathematical Education. 2021. Issue 3(29). P. 24-30. doi:10.31110/2413-1571-2021-029-3-004

6. Проектування програмних засобів доповненої реальності навчального призначення / О. В. Сироватський, С. О. Семеріков, С. О. Модло, Ю. В. Єчкало, С. О. Зелінська.Сотритеr Science \& Software Engineeing : proceedings of the 1st Student Workshop (CS\&SE@SW 2018), Kryvyi Rih, Ukraine, November 30, 2018. P. 193-225.

7. Доповнена реальність як засіб реалізації дистанційного навчання в умовах карантину / В. В. Ткачук, Ю. В. Счкало, А. С. Тарадуда, І. П. Стеблівець. Освітній дискурс. 2020. Вип. 22. С. 43-53.

8. Паламар С., Нежива Л. Методична модель застосування доповненої реальності на уроках читання в початковій школі. Педагогічна освіта: теорія і практика. Психологія. Педагогіка, 2020. №34. С. 6-13.

\section{References:}

1. Melnyk, I. Yu., Nefodova, H. D., \& Zadyrei, N. M. (2018). Dopovnena ta virtualna realnist yak resurs navchalnoi diialnosti studentiv [Augmented and virtual reality as a resource for students' learning activities]. Informatsiini tekhnolohii ta kompiuterne modeliuvannia - Information technology and computer modeling : materials of articles of the International scientific-practical conference (Ivano-Frankivsk, May 14-19, 2018). Ivano-Frankivsk: Mr. Goliney OM, 61-64. [in Ukrainian].

2. Zhytienova, N. V. (2016). Tekhnolohii vizualizatsii v suchasnykh osvitnikh trendakh. Vidkryte osvitnie e-seredovyshche suchasnoho universytetu, (2), 144-157. [in Ukrainian].

3. Honcharova, N. (2019). Tekhnolohiia dopovnenoi realnosti v pidruchnykakh novoho pokolinnia [Augmented reality technology in new generation textbooks]. Problemy suchasnoho pidruchnyka - Problems of the modern textbook, (22), 46-56. [in Ukrainian].

4. Korniienko, I. O. (2020). Augmented reality tools in education. Visnyk National Defence Unuversity of Ukraine, 57.4, 52-58.

5. Soroko, N. (2021). The augmented reality functions to support the STEAM education at general education institutions. Physical and Mathematical Education, 3(29), 24-30. doi:10.31110/2413-1571-2021-029-3-004

6. Syrovatskyi O. V., et al. (2018). Proektuvannia prohramnykh zasobiv dopovnenoi realnosti navchalnoho pryznachennia [Design of augmented reality software for educational purposes]. Computer Science \& Software Engineeing : proceedings of the 1st Student Workshop (CS\&SE@SW 2018), Kryvyi Rih, Ukraine, November 30, 193-225. [in Ukrainian].

7. Tkachuk, V. V., Yechkalo, Yu. V., Taraduda, A. S., \& Steblivets, I. P. (2020). Dopovnena realnist yak zasib realizatsii dystantsiinoho navchannia $\mathrm{v}$ umovakh karantynu [Augmented reality as a means of implementing distance learning in quarantine]. Educational discourse, 22, 43-53. [in Ukrainian].

8. Palamar, S. P., \& Nezhyva, L. L. (2020). Metodychna model zastosuvannia dopovnenoi realnosti na urokakh chytannia $\mathrm{v}$ pochatkovii shkoli [Methodical model of augmented reality application in reading lessons in primary school]. Pedahohichna osvita: teoriia i praktyka. Psykholohiia. Pedahohika - Pedagogical education: theory and practice. Psychology. Pedagogy, 34(2), 6-13. [in Ukrainian]. 